\title{
Antioxidant defences of Norway spruce bark against bark beetles and its associated blue-stain fungus
}

\author{
Mateja FELICIJAN ${ }^{\star *}$, Metka NOVAK ${ }^{2}$, Nada KRAŠEVEC ${ }^{3}$, Andreja URBANEK KRAJNC ${ }^{1}$ \\ ${ }^{1}$ University of Maribor, Faculty of Agriculture and Life Sciences, Pivola 10, 2311 Hoče, Slovenia \\ ${ }^{2}$ Karolinska Institutet, Stockholm, Sweden \\ ${ }^{3}$ National Institute of Chemistry, Ljubljana, Slovenia
}

\begin{abstract}
SUMMARY
Bark beetles and their fungal associates are integral parts of forest ecosystems, the European spruce bark beetle (Ips typographus Linnaeus, 1758) and the associated pathogenic blue stain fungus Ceratocystis polonica (SIEM.) C. MOREAU, are the most devastating pests regarding Norway spruce [Picea abies (L.) H. KARST.]. Bark beetles commonly inhabit weakened and felled trees as well as vital trees. They cause physiological disorders in trees by destroying a phloem and cambium or interrupt the transpiration flow in the xylem. Conifers have a wide range of effective defence mechanisms that are based on the inner bark anatomy and physiological state of the tree. The basic function of bark defences is to protect the nutrient-and energy-rich phloem, the vital meristematic region of the vascular cambium, and the transpiration flow in the sapwood. The main area of defence mechanisms is secondary phloem, which is physically and chemically protected by polyphenolic parenchyma (PP) cells, sclerenchyma, calcium oxalate crystals and resin ducts. Conifer trunk pest resistance includes constitutive, inducible defences and acquired resistance. Both constitutive and inducible defences may deter beetle invasion, impede fungal growth and close entrance wounds. During a successful attack, systemic acquired resistance (SAR) becomes effective and represents a third defence strategy. It gradually develops throughout the plant and provides a systemic change within the whole tree's metabolism, which is maintained over a longer period of time. The broad range of defence mechanisms that contribute to the activation and utilisation of SAR, includes antioxidants and antioxidant enzymes, which are generally linked to the actions of reactive oxygen species (ROS). The presented review discusses the current knowledge on the antioxidant defence strategies of spruce inner bark against the bark beetle (Ips typographus) and associated blue stain fungus (Ceratocystis polonica).
\end{abstract}

Key words: antioxidants, ascorbate-glutathione system, blue-stain fungus Ceratocystis polonica (SIEM.) C. MOREAU,

Norway spruce (Picea abies (L.) H. KARST.), phenolics, systemic acquired resistance (SAR)

\section{THE BIOLOGY BEHIND THE ASSOCIATION OF SPRUCE BARK BEETLE WITH BLUE-STAIN FUNGI}

Over their long lifetimes, conifers are targets of numerous attacks by different pests such as insects, other herbivores, fungi, and bacteria. They pave their way towards nutrient-rich phloem through the bark. Phloem and cambium represent a relatively small part of a tree's trunk, which could be even faster and more easily damaged and destroyed than other tissues (Franceschi et al. 2005).

The majority of bark beetle species are considered as rather harmless species in their native ranges, colonising mainly weakened or dead trees and thereby represent an important ecological factor in forest rejuvenation (Müller and Job 2009, Smith et al. 2011, Novak et al. 2014). However, these species pose potential risks in the case of significant increase in abundance of populations and within changing or new environments. They should not be ignored when evaluating

${ }^{*}$ Correspondence to:

E-mail:mateja.felicijan@um.si 
risks and threats to forest ecosystems or when determining quarantine measures for pests and pathogens. Forest pest insects and their associated micro-organisms are capable of movement through national boundaries and have a potential impact on forest-dependent industries (Christiansen and Bakke 1988, Linnakoski et al. 2012, Sallé et al. 2005, Raffa et al. 2008, Faccoli 2009, Smith et al. 2011).

One of the most destructive forest insects in Europe is the spruce bark beetle Ips typographus (Linnaeus 1758.) (Curculionidae, Scolytinae), which affects Norway spruce and is with its fungal associates, the pathogenic blue-stain fungus Ceratocystis polonica (SIEM.) C. MOREAU the integral parts of the forest ecosystems (Wermelinger 2004, Klepzig et al. 2009, Linnakoski et al. 2012, Novak et al. 2014). Their symbiotic relationship has been described as mutualistic (Whitney 1982). Although a number of studies have been devoted to resolving the nature of bark beetle-fungus interactions, these interactions remain poorly understood (Jurc 2011, Six and Wingfield 2011).

The fluctuations in bark beetles' populations are interactions between at least three main biological components: the host tree, bark beetles, and pathogen fungi (Novak 2014).

Normally has Ips typographus two (spring and summer) generations per year (Fig. 1). If global warming extends the growing season, a higher proportion of the second generation may reach the cold at the hardy adult stage and survive the winter (Holger et al. 2006). Bark beetles construct galleries under the bark within the phloem layers of woody plants, mostly in weakened or recently killed trees, where they lay eggs and their brood feed and develop during the winter (Six and Wingfield 2011).

Adult beetles form wounds through the bark into the phloem, as a source of food and the place of reproduction, to the cambium. Parental adults construct an initial egg gallery, which is continued by larvae into the larval galleries (Raffa et al. 2008). During the constructions of galleries, bark beetles serve as vectors for several types of micro-organisms that enter into the host tree. They benefit the fungus because it is transferred into a nutrient-rich environment, where competition is limited (Whitney 1982, Beaver 1989, Paine et al. 1997). Specific roles of fungal associates in the Ips typographus symbiotic system and some of its underlying molecular mechanisms have been the topics of considerable previous work (Krokene and Solheim 1998, Hammerbacher et al. 2013, Urbanek Krajnc et al. 2014).
Now it is known that within a symbiotic system bark beetles serve as vectors for fungi, which would otherwise be unable to reach a new host (Six and Wingfield 2011), alternatively fungi benefit the beetle as sources of nutrients, or they may weaken tree defences (Linnakoski et al. 2012). The concept that tree-killing bark beetles require fungal pathogens to overcome tree defences and to incur tree mortality has received the most attention over the years. This hypothesis, which is referred to as the classic paradigm, has formed the basis for the majority of research conducted on these interactions (Six and Wingfield 2011). Blue-stain fungi are thought to be primarily responsible (Johnson and Croteau 1987) or required (Whitney 1982) for mortality regarding conifers attacked by bark beetles.

Such conclusions are based on observations that:

- beetles are capable of vectoring or dispersing the fungi,

- beetles are rarely found in the absence of staining fungi,

- sapwood of beetle-killed trees is stained (Paine et al.

1997).

Although the mechanisms are not fully understood, a tree is killed as a result of the simultaneous activities and interactions of both organisms, rather than the successive actions of beetles and pathogen (Nebeker and Hodges 1993, Paine et al. 1997). On the other hand, Six and Wingfield (2011) suggest that fungal phytopathogenicity has a more important role for the fungi, rather than supporting the bark beetles in tree killing. It may be a factor helping the fungi to survive within a living tree.

\section{DEFENCE STRATEGIES OF NORWAY SPRUCE BARK}

Due to the variety of pests the conifers evolve complex anatomical and chemical defences against pathogen attack, which may deter beetle invasion, impede fungal growth, and seal entrance wounds (Rohde et al. 1996, Bonello et al. 2001, Baier et al. 2002, Wermelinger 2004, Franceschi et al. 2005). Bark anatomy and the physiological condition of a potential host tree are crucial for the success of an attack/ infection. Until now, three types of tree's defence strategies have been described: constitutive, induced defences and systemic acquired resistance (Franceschi et al. 2005). Defence mechanisms are based on the bark anatomy and

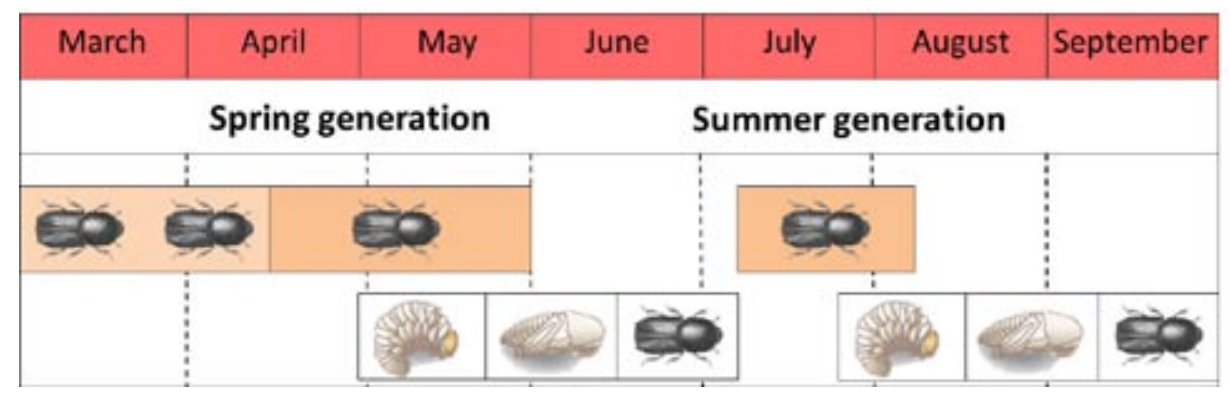

Fig.1: Generalised life-cycle of the spruce bark beetle (I. typographus), which normally has two generations per year - spring and summer generations. Bark beetles construct galleries, lay eggs and at the same time inoculate fungi into the bark phloem of woody plants(Six and Wingfield 2011). 
its physiological condition. The main area of defence mechanisms is secondary phloem, which represents both physical and chemical protections (Hudgins and Franceschi 2004).

\section{Constitutive and induced defence}

An effective defence is provided by a multi-stage system, which runs as a series of different resistance mechanisms. Conifer trunk includes constitutive and inducible defences, which have attracted much attention over recent years. Most of the new knowledge has been obtained on resin-producing and resin-storing structures. Furthermore, quantitative and qualitative changes in the local metabolism have been studied around the entrance hole. These investigations have focused on phenolics, terpenoids and protein-based chemical defences (Brignolas et al. 1998, Evensen et al. 2000, Nagy et al. 2004, Wermelinger 2004, Franceschi et al. 2005, Erbilgin et al. 2006, Zeneli et al. 2006). Without prior attack the bark implements mechanical and chemical constitutive passive defence mechanisms. It involves initiation of a wound periderm, and based on bark anatomy also formation of cells with phenols, resin ducts, concentric layers of polyphenolic parenchyma (PP) cells, sclerenchyma and calcium oxalate crystals (Hudgins and Franceschi 2004, Franceschi et al. 2005, Hudings et al. 2004, Krekling et al. 2004).

An invasion activates inducible defence systems, which include secondary resin production, synthesis of new phenolics, and protein-based chemical defences. The induced defence detects attacks and closes the initial wounds by the formation of resin ducts, which contribute to increased synthesis of terpenes and resin flow. The induced defence is more effective and represents a more sustainable method of defence, as is provided by qualitative and quantitative changes in the chemical compositions of the trees' metabolisms. Furthermore, induced defence increases the formations of new PP cells and phenolic compounds, which are toxic for invasive organisms (Hudgins and Franceschi 2004, Franceschi et al. 2005, Schmidt et al. 2005, Witzel and Martin 2008). Pathogens use mechanical force or release cell wall degrading enzymes to break down this barrier. At the cell wall, they also trigger pathogen-associated molecular patterns (PAMPs) either inadvertently or as a consequence of plant degradative enzymes (e.g. the release of chitin oligomers by plant chitinases). Plants, in turn, appear to sense these PAMPs and damage to their cell walls and activate a variety of defences, including the production of reactive oxygen species (ROS), the production and export of anti-microbial compounds and fortification of their cell walls. PAMPs also activate a localised and systemic acquired resistance (LAR and SAR), initiating the synthesis of pathogenesis-related proteins (PR proteins), installation of lignin and accumulation of phenols and toxins (Hématy and et al. 2009). In addition, sensing PAMPs may activate intracellular defences such as the salicylic acid pathway, perhaps priming the plant for the next stage of warfare.

Collectively, constitutive and inducible compounds may deter beetle invasion, impede fungal growth, and seal entrance wounds (Bonello et al. 2001, Nagy et al. 2004, Wermelinger
2004, Franceschi et al. 2005, Zeneli et al. 2006, Rodrigues et al. 2009).

\section{SAR - systemic acquired resistance}

The last and very important defence strategy is composed of a systemic acquired resistance (SAR), which becomes affective during successful attack and ensures faster and easier responses to attacks in the future (Evensen et al. 2000, Percival 2001, Nagy et al. 2004, Franceschi et al. 2005, Bonello et al. 2006, Witzel and Martin 2008). This mechanism gradually develops throughout the plant during pest colonisation, and provides a systemic change in the whole tree metabolism. This leads to the production of fewer carbohydrates but more proteins, which are needed for defence (Viiri et al. 2001, Wermelinger 2004). The broad range of defence mechanisms, which contribute to the appearance of SAR, include antioxidants (ascorbic acid, cysteine, glutathione, total phenols) and antioxidant enzymes (Foyer and Rennenberg 2000, Riedle-Bauer 2000, Urbanek Krajnc 2004, 2009), which are generally linked to the actions of ROS (Hayat et al. 2009). Although anti-oxidative defence systems are often used as stress indicators for the diagnosis of disturbances in forest trees (Foyer and Rennenberg 2000, Riedle-Bauer 2000, Tausz et al. 2003, 2004, Grill et al. 2001, Tegischer et al. 2002), to date only a few investigations have dealt with anti-oxidative system of attacked Norway spruce (Urbanek Krajnc 2009, Urbanek Krajnc et al. 2014).

While several studies have demonstrated that the induction of phenolics occurs on a local scale (Evensen et al. 2000, Franceschi et al. 2000, 2005), several recent studies have also found evidence of the systemic induction of soluble low molecular weight phenolics (Bonello et al. 2001, 2006, Wallis et al. 2008). A SAR hypothesis postulated by Bonello et al. (2006) illustrated the interplay between SAR and induced susceptibility in trees against microbes and herbivores. The authors postulated that the time course of pathogen infection may have a bell-shaped effect on the strength of SAR that is similar to the spatial variations of constitutive secondary metabolites generated by resource availability. In the earliest stages of pathogen infection, SAR responses are predicted to rapidly and systemically increase concentrations of compounds involved in defence against pathogens and insects. However, if the pathogen is able to grow despite the deployment of localised defence responses, the infection will progress, and the tree will become increasingly stressed by the resulting resource limitations (e.g. reduction of sap flow, limited nutrient and water absorption, decreased carbon assimilation and growth). Consequently, a degradation of molecules involved in SAR would follow.

SAR has been actively studied in herbaceous plant species, and, over recent years, in woody plant species (Bonello et al. 2006, Eyles e tal. 2009), and is fast emerging as an intriguing, eco-friendly concept for enhancing tree resistance. However, before applying SAR becomes possible, there is a need to increase our knowledge of the mechanisms of defence in forest trees. Over recent years, research has focused on studying the impact of exogenous methyl jasmonate (MJ) and SA treatment on the inductions of certain metabolites 
which are involved in SAR. Many authors (Franceschi et al. 2002, Hudings and Franceschi 2004, Hudings et al. 2004, Schmidt et al. 2005, Erbilgin et al. 2006) have examined the effect of MJ treatment in combination with the induced resistance of Norway spruce, where the positive impacts have been observed of MJ treatment and bark beetle attacks or Ceratocystis polonica infection. They reported that MJ treatment stimulated the synthesis and accumulation of terpenes (Kozlowski et al. 1999, Franceschi et al. 2002, Martin et al. 2002, 2003, Fäldt et al. 2003, Hudgins and Franceschi 2004, Hudgins et al. 2004, Miller et al. 2005, Erbilgin et al. 2006, Zeneli et al. 2006).

In our previous field experiment (Urbanek Krajnc et al. 2011), $100 \mathrm{mM} \mathrm{SA}$ was applied to the bark sections of Norway spruce prior to being attacked by bark beetles, in order to study interactions with antioxidants and their significance for mediating stress-tolerance under natural conditions. SA-treatments significantly elevated the total SA levels over the whole sampling period. Total glutathione (tGSH) and total cysteine (tCys) increased, respectively, two weeks after treatment, in comparison with controls. One month after pheromone dispensers were placed on trees, an intensification of the ascorbate-glutathione system occurred within moderately-affected bark but to a greater extent after SA-treatment. Total SA levels within SA-treated moderatelyaffected trees remained at the control level until June. In contrast, strong attack was characterised by a successive increase in total SA and degradation of tGSH as well as total phenolics ( $\mathrm{tPH})$, a moderate increase in total ascorbate (tASC) and an oxidation of the ascorbate-glutathione pool within non-treated bark.

Furthermore, at the end of the three month experiment, the SA-treated bark had less entrance holes, and exhibited fewer and shorter maternal galleries than the control-bark. From this perspective, exogenous SA was successfully implicated as an activator of SAR in Norway spruce, providing tolerance against the complex interactive effects of bark beetle attack and environmental factors (Urbanek Krajnc et al. 2011).

\section{OXIDATIVE STRESS AND ANTIOXIDANT RESPONSE OF CONIFER METABOLISMS}

Antioxidants play an important role in chemical defence as they prevent the oxidations of other substances such as inactivate oxygen compounds and inhibit the formations of free radicals (Brodnjak Vončina 2006). Antioxidants are classified into three groups: real antioxidants that bind free radicals; reducing agents, while the third group consists of antioxidant synergists (Kugler 2011).

Both biotic and abiotic stress factors trigger plant metabolism changes and mostly react with the reactive oxygen species (ROS; $\mathrm{H}_{2} \mathrm{O}_{2}$ ). Oxidative stress reflects an imbalance between the systemic manifestations of reactive oxygen species and a biological system's ability to readily detoxify the reactive intermediates or to repair the resulting damage. Disturbances in the normal redox states of cells can cause toxic effects through the production of peroxides and free radicals that damage all components of the cell.
Antioxidants can slow down or even totally stop the oxidations of these molecules by hunting the free radicals and by removing oxidative damaged biomolecules (Kugler 2011, Veberič 2010, Harris and Hansen 2012). The antioxidants do not accumulate in the cytoplasm but in the vacuoles and other organelles such as plastids and mitochondria, where they are urgently needed as an effective "redox shuttle" (Kreft et al. 2000).

\section{Phenolics}

Among antioxidants phenolics represent a more important component of the inducible defence strategy regarding conifer bark. They range from simple, low molecular weight, single aromatic-ringed compounds to large and complex tannins and derived at polyphenols that provide different chemical and structural defence strategies.

In regard to the synthesis and accumulation of phenolic compounds, the barks of all conifer families have polyphenolic parenchyma cells (Krekling et al. 2000, Franceschi et al. 2000, 2005, Schmidt et al. 2005). Within their vacuoles, polyphenolic parenchyma cells contain variable amounts of phenolic bodies that are thought to serve as antifeedant and antifungal agents (Beckman 2000). Polyphenolic parenchyma cells are also major sites for storing starch and lipids (Krekling et al. 2000). In this capacity, they can be seen as targets for beetles and fungi, and constitutive phenolics can be hypothesised to protect the cells themselves, as well as prevent fungal penetration towards the cambial zone. In any case, the multiple layers of polyphenolic parenchyma cells providing physical and chemical resistance to penetration of the bark (Franceschi et al. 2000, 2005, Schmidt et al. 2005).

In our previous study on Norway spruce, the increase in total phenolics' concentrations two weeks after a bark beetle attack was recognized as an immediate inducible response to the attack (Urbanek Krajnc 2009, Urbanek Krajnc et al. 2011). Additionally, phenolics accumulated, to a higher extent, in the control tissue, which was explained as a wound reaction induced by mechanical injury (Christiansen et al. 1999, Franceschi et al. 2005, Ralph et al. 2006, Urbanek Krajnc 2009). The increase in total phenolics during the initial bark beetle colonisation was accompanied by the degradations of total ascorbic acid and tGSH, as well as oxidation of the ascorbate-glutathione pool. These initial events pointed out that the antioxidant defence is a multi-tier system with a spatial and temporal component. The spatial component is determined by the positions of PP cells' concentric rings from the periderm surface to the cambial zone (Franceschi et al. 2005) and the temporal component consisted of seasonal, continuous and enhanced production of phenolics in the attacked tissue. However, at later sampling dates, the trees with moderate attack were characterised by increased and steady-states of the $\mathrm{tPH}$ concentration, whereas the strong attacks were shown by drastically decreased concentrations of tPH (Urbanek Krajnc 2009). As the PP cells are the primary sites of phenolic biosynthesis within the secondary phloem (Franceschi et al. 2000, 2002, 2005), an assumption can be made that the synthesis of phenolics is lacking when the phloem is damaged, by the establishment of a complete 
breeding system.

The more important phenolics in the Norway spruce phloem are stilbenes, flavonoids, as well as tannins (e.g. Lieutier et al. 2003, Schmidt et al. 2005, Witzell and Martin 2008, Hammerbacher et al. 2011). In general, phenolics fulfil different defensive functions. Most of the phenolics contribute to resistance indirectly. For instance, some low molecular weight phenolic compounds may function as precursors for other defensive compounds (e.g. lignin; Bonello and Blodgett 2003), or they may confer resistance as a group, rather than as individual compounds (Wallis et al. 2008). Catechin is a building block of condensed tannins for which antimicrobial activity via protein precipitation and iron depletion has been suggested (Witzell and Martin 2008).

Significant quantities of stilbene in pine bark were found years ago (Sjöström 1993), while now it is known that pine bark extract contains several types of stilbene (the more important being astringin and isorapontin) and flavonoids. Changes in the concentrations of stilbenes and flavonoids in Norway spruce in response to injury or fungal infection are considered to be an active defence response (Brignolas et al. 1995, 1998, Viiri et al. 2001, Havsteen 2002, Schmidt et al. 2005, Witzell and Martin 2008, Li et al. 2012, Hammerbacher et al. 2011, 2013). Stilbenes are known to inhibit fungal growth by interfering with microtubule assembly (Woods et al. 1995, Adrian et al. 1997), disrupting plasma membranes and uncoupling electron transport within fungal spores and germ tubes (Pont and Pezet 2008, Adrian and Jeandet 2012). Stilbenes have also been shown to protect plants against oxidative stress (He et al. 2008), to deter herbivores (Torres et al. 2003), and to inhibit the growth of competing plants (Fiorentino et al. 2008).

Specific phenolic compounds in spruce inner bark against Ceratocystis polonica infection were previously interpreted by Urbanek Krajnc et al. (2014). Increases in $\mathrm{tPH}$, catechin, astringin, isorhapontin and taxifolin were monitored. By analysing each single phenolic compound, on later sampling dates, it could be observed that within certain time shifts the phenolics followed the eco-physiological concept and basically fit with the temporal sequence of changes in tPH concentrations after the moderate bark beetle attack, previously reported on the spruce/bark beetle pathosystem (Urbanek Krajnc 2009, Urbanek Krajnc et al. 2011). The initial decline in catechin was followed by an increase in catechin concentration until September, when taxifolin accumulated within the infected bark at significantly higher levels until June, and later the concentrations dropped toward the control levels. On the other hand, a slight accumulation of astringin observed in response to fungi infection, when the concentration at later sampling dates dropped. The same was for isorhapontin concentration, where a dramatic initial increase was observed, and later it simply diminished (Urbanek Krajnc et al. 2014).

\section{Ascorbate-glutathione cycle}

Besides phenolics, ascorbate-glutathione system plays an important role in plant metabolism and defence. The ascorbate-glutathione cycle is considered to be the main pathway for ROS removal, and both ascorbate and glutathione are recognised as the heart of the redox hub within the cell (Foyer and Noctor 2012).

Amongst antioxidants, glutathione is a low molecular sulphur metabolite, which plays multiple roles within treeenvironment interactions and defences (Grill et al. 2001, Tausz et al. 2004, Zhao et al. 2008, Noctor 2006, 2012). It functions as a reductant in the enzymatic detoxification of ROS within the glutathione-ascorbate cycle and as a thiol buffer in the protection of proteins via direct reaction with ROS or by the formation of mixed disulphides (Zhao et al. 2008). In this role it has been suggested as a general redox sensor and signalling agent in plant cells (Meyer and Hell 2005, Cameron and Pakrasi 2010, Noctor et al. 1998, 2012).

Owing to its redox-active thiol group, GSH has often been considered as playing an important role in plant defence against oxidative stress (Grant et al. 1996). Trees under stress seem to generally require and synthetise higher concentrations of glutathione (Gullner and Kömives 2001, Tausz et al. 2003, 2004). Glutathione synthesis depends on

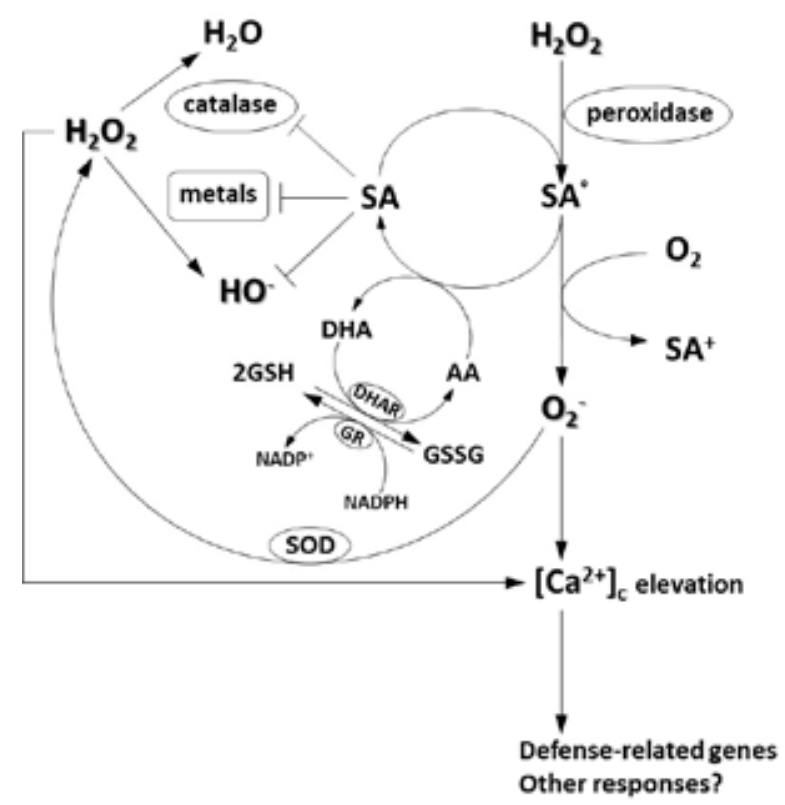

Fig. 2: A model for the mechanism of SA action within the generation of active oxygen species, which induces the expression of the defence-related genes via an increase in $\left[\mathrm{Ca}^{2+}\right]_{c}$. SA and a trace of $\mathrm{H}_{2} \mathrm{O}_{2}$ are used for the $\mathrm{SA}^{-g e n e r a t i n g}$ peroxidase reaction. Then the resultant $\mathrm{SA}^{\prime}$ reacts with $\mathrm{O}_{2}$ to produce $\mathrm{O}_{2}^{-}$ that triggers an increase in $\left[\mathrm{Ca}^{2+}\right]_{c}$. The increased $\left[\mathrm{Ca}^{2+}\right]_{\mathrm{c}}$ may induce further physiological responses including the induction of PR genes. Ascorbate reconverts SA to SA yielding monodehydroascorbate. An excess of ascorbate may inhibit the $\mathrm{SA}^{-}$ dependent generation of $\mathrm{O}_{2}^{-}$. While the generation of $\mathrm{O}_{2}^{-}$is going on, $\mathrm{SA}$ inhibits the decomposition of $\mathrm{H}_{2} \mathrm{O}_{2}$ by catalase and a Fenton-type reaction. SA also lowers the HO level by blocking the Fenton reaction and by directly trapping $\mathrm{HO}$. Thus SA protects the cells from highly reactive $\mathrm{HO}$, while producing the less reactive $\mathrm{O}_{2}^{-}$and $\mathrm{H}_{2} \mathrm{O}_{2}$ through a peroxidase-catalysed reaction, as the intermediate signals. 
the distribution and cycling of sulphur in trees. Glutathione biosynthesis is restricted to the cytosol and the plastids, but mitochondria, which lack the capacity for glutathione biosynthesis, have been described as major sites of glutathione accumulations (Zechmann et al. 2007).

In all cells where GSH is found, besides reduced tripeptide form, the oxidised form of GSH (glutathione disulphide: GSSG) is also present in small quantities (<20\%). While glutathione reductase (GR) uses NADPH to reduce GSSG to $\mathrm{GSH}$, various free radicals and oxidants are able to oxidise GSH to GSSG (Fig. 2).

Both GSH and GSSG are considered as markers of oxidative stress in the plant, by increasing the antioxidant pool and as actors in cell signalling. Based on the current understanding of redox status and the roles of ROS, thiols, oxidisers and cellular antioxidants, scientists have redesigned a definition of oxidative stress (Harris and Hansen 2012), now it is based on changes in translation of thiol proteins, important for the control of the redox potential. Thiol redox couples such as GSH / GSSG, cysteine / cystine (Cys / cySS) form independent centres within the cells, which are linked to changes in the redox potential.

Glutathione is central to the regeneration of ascorbate within the ascorbate-glutathione cycle (Tausz et al. 2003, 2004). Glutathione, as an antioxidant, together with ascorbate, removes ROS, including hydrogen peroxide, superoxide and hydroxide radicals, which generate in cells as a result of oxidative stress (Xiang et al. 2001, Alscher 2006). In addition to being the most abundant water-soluble antioxidant in plant cells (Smirnoff and Wheeler 2000), ascorbic acid (AA) is also required for the re-conversion of $\mathrm{SA}$, as ascorbate is highly reactive against phenoxyl radicals generated by peroxidases during oxidative stress (Fig. 2) (Kawano and Muto 2000, Smirnoff and Wheeler 2000). Together with glutathione, it is present in oxidation-reduction processes within the ascorbate-glutathione cycle. Dehydroascorbate (DHA) formed when ascorbate is oxidised, must be reduced again in order to prevent decreases in the total ascorbate pool (Likar and Regvar 2003, Šuštaršič 2012). At alkaline $\mathrm{pH}$ values, GSH rapidly reduces DHA to ascorbate in a nonenzymic reaction. In plant tissues this reaction is catalysed by dehydroascorbate reductase (DHAR) (Noctor et al. 1998). The ascorbate glutathione cycle is essential for the removal of ROS and connects the conversion of ascorbic acid and glutathione.

Ascorbic acid is due to the two hydroxyl groups being one of the stronger reductants in the cell and allows the detoxification of reactive oxygen species. In the cell metabolism AA operates in oxidation-reduction processes, in the ascorbate-glutathione chain, where it is reversibly oxidised to DHA. At this stage, the oxidised form of ascorbic acid is restored via glutathione, when the GSH is oxidised to GSSG, and at the same time increases the GSSG / GSH ratio and the activity of GR (Foyer and Noctor 2012).

Although the antioxidant response is relatively welldocumented on the level of spruce needles (Tegischer et al. 2002, Tausz et al. 2004), there is little known about changes in the ascorbate-glutathione chain at the inner bark level during bark beetle and fungus infection. In two of our previous experiments, the roles of thiols and ascorbate in the spruce inner bark were studied during the five month sampling period after the spruce inner bark was exposed to beetle attack and Ceratocystis polonica infection (Urbanek Krajnc 2009, Urbanek Krajnc et al. 2014).

The initial reaction of Norway spruce to Ceratocystis polonica infection was characterised by a significantly more oxidised glutathione pool which was accompanied by higher GR activity. At the same time, the tCys dropped slightly below the levels of the non-infected samples and the cysteine redox state shifted towards a more oxidised value. Similarly, in one of the previous experiments, 2 weeks after the exposures of spruce trees to bark beetles slight but insignificant decreases were measured for tCys as well as tGSH, which were accompanied by a slightly more oxidised glutathione redox state (Urbanek Krajnc 2009). Until July, the infected inner bark was characterised by a gradual increase in $\mathrm{tGSH}$, which was accompanied by a significantly increasing GR activity. Furthermore, within the infected inner bark the tCys remained elevated over the whole sampling period. Based on a previous experiment Urbanek Krajnc et al. (2009, 2014), concluded that the antioxidant shift within the Ceratocystis polonica infected bark indicated a successful defence reaction, which was characterised by a higher accumulation of thiols and a more reduced redox state. In September, the glutathione system reached a steady-state, and the GR activity and tCys concentrations remained increased. Consequently, thiols accumulated in May were accompanied by a significant degradation of tASC within the Ceratocystis polonica infected inner bark until July, followed by a significant accumulation in September. However, when comparing the tASC contents in the Ceratocystis polonica infected samples, the concentrations increased continuously from the spring onwards to September, which reflected increased pressure on the ascorbate-glutathione cycle (Urbanek Krajnc 2009, 2014).

\section{CONCLUSIONS}

Our previous field experiments (Urbanek Krajnc 2009, Urbanek Krajnc et al. 2011, 2014) demonstrated that the sequence of changes in the endogenous levels of antioxidant molecules within the affected Norway spruce inner bark strengthened the general eco-physiological stress-response concept as suggested by Larcher (2003) and Tausz et al. (2004).

The time-course analysis of the individual molecules enabled us to establish a relationship between salicylic acid, phenolics and the ascorbate-glutathione system in response to the complex interactive effects of bark beetle attack, infection by blue-stain fungus, and environmental factors (Urbanek Krajnc 2009, Urbanek Krajnc et al. 2011, 2014). Based on the ascorbate-glutathione concept of Foyer and Noctor (2011), phenolics within the concentric layers of PP cells can be viewed as a wheel of the bark defence mechanism, driven by the ascorbate-glutathione system, as a central part or redox hub of the wheel that integrates metabolic information and environmental stimuli to tone defence responses against pathogen and pests. The presented article reviewes the current knowledge on physiological and biochemical defense 
responses of Norway spruce defence against bark beetles and associated fungi and also allows predictions of antioxidative defence responses in other conifer pathosystems.

\section{REFERENCES}

1. Adrian M, Jeandet P, Veneau J, Weston LA, Bessis R. Biological activity of resveratrol, a stilbenic compound from grapevines, against Botrytis cinerea, the causal agent for grey mould. J. Chem. Ecol. 1997;23:1689-1702.

2. Adrian $\mathrm{M}$ and Jeandet $\mathrm{P}$. Effects of resveratrol on the ultrastructure of Botrytis cinerea conidia and biological significance in plant/pathogen interactions. Fitoterapia 2012;83:1345-1350.

3. Alscher RG. Biosynthesis and antioxidant function of glutathione in plants. Physioi. Plantarum 2006;77:457464.

4. Baier P, Führer E, Kirisits T, Rosner S. Defence reactions of Norway spruce against bark beetles and the associated fungus Ceratocystis polonica in secondary pure and mixed species stands. For. Ecol. Manage. 2002;159:73-86.

5. Beaver RA. Insect-fungus relationship in the bark and ambrosia beetles. In: Wilding NM, Collins PMH and JFW (Eds). Insect-Fungus Interactions. San Diego, CA, Academic Press, 1989;119-143.

6. Beckman $\mathrm{CH}$. Phenolic-storing cells: keys to programmed cell death and periderm formation in wilt disease

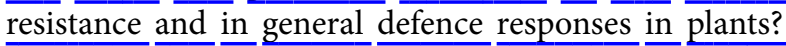
Phys. Mol. Plant Path. 2000;57:101-110.

7. Bonello P, Gordon TR, Storer AJ. Systemic induced resistance in Monterey pine. For. Pathol. 2001;31:99106.

8. Bonello P, Blodgett JT. Pinus nigra-Sphaeropsis sapinea as a model pathosystem to investigate local and systemic effects of fungal infection of pines. Physiol. Mol. Plant Pathol. 2003;63:249-261.

9. Bonello P, Gordon TR, Herms DA, Wood DL, Erbilgin N. Nature and ecological implications of pathogen-induced systemic resistance in conifers: A novel hypothesis. Physiol. Mol. Plant Pathol. 2006;68(4-6):95-104.

10. Brignolas F, Lacroix B, Lieutier F, Sauvard D, Drouet A, Claudot AC, Yart A, Berryman AA, Christiansen E. Induced responses in phenolic metabolism in two Norway spruce clones after wounding and inoculations with Ophiostoma polonicum, a bark-beetle associated fungus. Plant Physiol. 1995;109(3):821-827.

11. Brignolas F, Lieutier F, Sauvard D, Christiansen E, Berryman AA. Phenolic predictors for Norway spruce resistance to the bark beetle Ips typographus (Coleoptera: Scolytidae) and an associated fungus, Ceratocystis polonica. Can. J. For. Res. 1998;28:720-728.

12. Brodnjak Vončina D. Antioksidanti Analizna kemija II, Univerza v Mariboru, Fakulteta za kemijo in kemijsko tehnologijo. 2006.

13. Cameron JC and Pakrasi HB. Essential role of glutathione in acclimation to environmental and redox perturbations in the cyanobacterium synechocystis sp. PCC 6803. Plant Physiol. 2010;154: 1672-1685.
14. Christiansen E in Bakke A. The spruce bark beetle of Eurasia. In: Berryman AA (Ed). Population ecology: theory and application. New York,Plenum Press, 1988;479-503.

15. Christiansen E, Krokene P, Berryman AA, Franceschi VR, Krekling T, Lieutier F, Lonneborg A, Solheim H. Mechanical injury and fungal infection induce acquired resistance in Norway spruce. Tree Physiol. 1999;19:399403.

16. Erbilgin N, Krokne P, Christian E, Zeneli G, Gershenzon J. Exogenous application of methyl jasmonate elicits defenses in Norway spruce (Picea abies) and reduces host colonization by the bark beetle Ips typographus. Oecologia 2006;148:426-436.

17. Evensen PC, Solheim H, Hoiland K, Stenersen J. Induced resistance of Norway spruce, variation of phenolic compounds and their effects on fungal pathogens. Forest Pathol. 2000;30:97-108.

18. Eyles A, Bonello P, Ganley R, Mohammed C. Induced resistance to pests and pathogens in trees. New Phytol. 2009; 185:893-908.

19. Fäldt J, Martin D, Miller B, Rawat S, Böhlmann J. Traumatic resin defense in Norway spruce (Picea abies): methyl jasmonate-induced terpene synthase gene expression, and cDNA cloning and functional characterization of (+)-3-carene synthase. Plant Mol. Biol. 2003;51:119133.

20. Felicijan M. Časovna analiza vsebnosti kondenziranih taninov v lubju navadne smreke pri napadu podlubnikov. Univerza v Mariboru. Fakulteta za kmetijstvo in biosistemske vede. Diplomsko delo 2011.

21. Foyer $\mathrm{CH}$, Rennenberg H. Regulation of glutathione synthesis and its role in abiotic and biotic stress defence. In: Brunold C, Rennenberg H, De Kok LJ, Stulen I, Davidian J-C (Eds). Sulfur nutrition and sulfur assimilation in higher plants. Paul Haupt, Bern 2000;127-153.

22. Foyer $\mathrm{CH}$ in Noctor G. Ascorbate and glutathione: the heart of the redox hub. Plant Physiol. 2011;155:2-18.

23. Franceschi VR, Krokene P, Krekling T, Christiansen E. Phloem parenchyma cells are involved in local and distant defense responses to fungal inoculation or barkbeetle attack in Norway spruce (Pinaceae). Am. J. Bot. 2000;87:314-326.

24. Franceschi VR, Krekling T, Christiansen E. Application of methyl jasmonate on Picea abies (Pinaceae) stems induces defense-related responses in phloem and xylem. Am. J. Bot. 2002;89(4):578-586, 602-610.

25. Franceschi VR, Krokene P, Christiansen E, Krekling T. Anatomical and chemical defenses of conifer bark against bark beetles and other pests. New phytol. 2005;167(2):353-376.

26. Grant CM, MacIver FH, Dawes IW. Glutathione is an essential metabolite required for resistance to oxidative stress in the yeast Saccharomyces cerevisiae. Curr. Genet. 1996;29(6):511-515.

27. Grill D, Tausz M and De Kok LJ. Significance of glutathione in plant adaptation to the environment. In: De Kok LJ (Ed). Handbook of Plant Ecophysiology. Kluwer Academic Publishers, Dordrecht, 2001.

28. Gullner G, Komives T. The role of glutathione and glu- 
tathione-related enzymes in plant-pathogen interaction. In: Grill D, Tausz M, De Kok LJ (Eds). Significance of glutathione to plant adaptation to the environment. Kluwer Academic Publishers, Dordrecht, Boston, London, 2001;207-239.

29. Hammerbacher A, Ralph SG, Bohlmann J, Fenning TM, Gershenzon J, Schmidt A. Biosynthesis of the major tetrahydroxystilbenes in spruce, astringin and isorhapontin, proceeds via resveratrol and is enhanced by fungal infection. Plant Physiol. 2011;157:876-890.

30. Hammerbacher A, Schmidt A, Wadke N, Wright LP, Schneider B, Bohlmann J, Brand WA, Fenning TM, Gershenzon J, Paetz C. A common fungal associate of the spruce bark beetle metabolizes the stilbene defenses of Norway spruce. Plant Physiol. 2013;162:1324-1336.

31. Harris C, Hansen JM. Oxidative stress, thiols, and redox profiles. Methods Mol. Biol. 2012;889:325-46.

32. Hayat Q, Hayat S, Ifran M Ahmad A. Effect of exogenous salicylic acid under changing enviroment: A review. Envirom. Exp. Bot. 2009;68:14-25.

33. Havsteen BH. The biochemistry and medical significance of the flavonoids. Pharmacol. Ther. 2002;96(2-3):67202.

34. He S, Wu B, Pan YJ, Jiang LY. Stilbene oligomers from Parthenocissus laetevirens: isolation, biomimetic synthesis, absolute configuration, and implication of antioxidative defense system in the plant. J. Org. Chem. 2008;73(14):5233-5241.

35. Holger L, Bjørn $\varnothing$ and Krokene P Thresholds in the life cycle of the spruce bark beetle under climate change. Int. J. 2006;1-10.

36. Hudings JW, Christiansen E, Franceschi VR. Induction of anatomically based defense responses in stems of diverse conifers by methyl jasmonate: a phylogenetic perspective. Tree Physiol. 2004;24:251-264.

37. Hudings JW and Franceschi VR. Methyl jasmonateinduced ethylene production in responsible for conifer phloem defense responses and reprogramming of stem cambial zone for traumatic resin duct formation. Plant Physiol. 2004;135(4):2134-2149.

38. Johnson MA and Croteau R. Ecology and metabolism of plant lipids In: Fuller G and Nes WD (Eds). Washington DC, American Chemical Society, 1987.

39. Jurc M. Gozdna zoologija. Ljubljana. Biotehniška fakulteta. Oddelek za gozdarstvo in obnovljive gozdne vire. Narodna in univerzitetna knjižnica. 2011.

40. Kawano T and Muto S. Mechanism of peroxidase actions for salicylic acid induced generation of active oxygen species and an increase in cytosolic calcium in tobacco cell suspension culture. J. Exp. Bot. 2000;345(51):685693.

41. Klepzig KD, Adams AS, Handelsman J, Raffa KF. Symbioses: A key driver of insect physiological processes, ecological interactions, evolutionary diversification, and impacts on humans. Environ. Entomol. 2009;38(1):6777.

42. Kozlowski G, Buchala A, Metraux JP. Methyl jasmonate protects Norway spruce (Picea abies (L.) Karst.) seedlings against Pythium ultimum Trow. Phys. Mol. Plant Path. 1999;55(1):53-58.
43. Kreft I, Škrabanja V, Bonafaccia G. Temelji prehranskih in biotskih vplivov antioksidantov. In: Žlender B, Gašperlin L. (Eds). Antioksidanti v živilstvu. 20. Bitenčevi živilski dnevi 2000. Ljubljana, Biotehniška fakulteta, Oddelek za živilstvo. 2000;33-37.

44. Krekling T, Franceschi VR, Berryman AA, Christiansen E. The structure and development of polyphenolic parenchyma cells in Norway spruce (Picea abies) bark. Flora 2000;195:354-369.

45. Krekling T, Franceschi VR, Krokene P, Solheim H. Differential anatomical responses of Norway spruce stem tissues to sterile and fungus infected inoculations. Trees 2004;18:1-9.

46. Krokene P and Solheim H. Pathogenicity of four bluestain fungi associated with aggressive and nonaggressive bark beetles. Phytopatology 1998;88:39-44.

47. Krokene $\mathrm{P}$ and Solheim $\mathrm{H}$. What do low-density inoculations with fungus tell us about fungal virulence and tree resistance?. In: Lieutier F, Mattson WJ and Wagner MR (Eds). Physiology and genetics of treephytophage interactions. INRA Editions Versailles, France, 1999;353-362.

48. Kugler N. Vpliv temperature in čas ekstrakcije na vsebnost antioksidativnih učinkovin iz iglavcev. Univerza $\mathrm{v}$ Mariboru, Fakulteta za kemijo in kemijsko tehnologijo. Diplomsko delo 2011.

49. Larcher, W. Physiological plant ecology. Springer Verlag, Berlin, 2003.

50. Li S-H, Nagy NE, Hammerbacher A, Krokene P, Niu X-M, Gershenzon J, Schneider B. Localization of phenolics in phloem parenchyma cells of Norway spruce (Picea abies). ChemBio-Chem. 2012;13:2707-2713.

51. Lieutier F, Brignolas F, Sauvard D, Yart A, Galet C, Brunet M, Van de Sype H. Intra- and inter-provenance variability in phloem phenols of Picea abies and relationship to a bark beetle-associated fungus. Tree Physiol. 2003;23(4):247-256.

52. Linnakoski R, Beer ZW, Niemelä P, in Wingfield MJ. Associations of conifer-infesting bark beetles and fungi in fennoscandia. Insects 2012;3:200-227.

53. Likar $M$ and Regvar M. Praktikum fiziologije rastlin. Ljubljana, Študentska založba. 2003;94.

54. Malá J, Hrubcová M, Máchová $\mathrm{P}$, Cvrčková $\mathrm{H}$, Martincová $\mathrm{O}$, Cvikrová M. Changes in phenolic acids and stilbenes induced in embryogenic cell cultures of Norway spruce by two fractions of Sirococcus strobilinus mycelia. J. For. Sci. 2011;57:1-7.

55. Martin D, Tholl D, Gershenzon J, Bohlmann J. Methyl jasmonate induces traumatic resin ducts, terpenoid resin biosynthesis, and terpenoid accumulation in

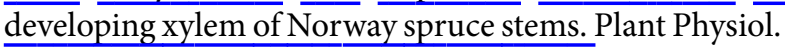
2002;129:1003-1018.

56. Martin D, Gershenzon J, Bohlmann J. Induction of volatile terpene biosynthesis and diurnal emission by methyl jasmonate in foliage of Norway spruce. Plant Physiol. 2003;132:1586-1599.

57. Meyer AJ and Hell R. Glutathione homeostasis and redox-regulation by sulfhydryl groups. Photosynth. Res. 2005;86:435-457.

58. Miller B, Madilao LL, Ralph S, Bohlmann J. Insect- 
induced conifer defense: White pine weevil and methyl jasmonate induce traumatic resinosis, de novo formed volatile emissions, and accumulation of terpenoid synthase and octadecanoid pathway transcripts in Sitka spruce. Plant Physiol. 2005;137:369-382.

59. Müller $\mathrm{M}$ and Job H. Managing natural disturbance in protected areas: Tourists attitude towards the bark beetle in a German national park. Biol. Conserv. 2009;142:375383.

60. Nagy NE, Fossdal CG, Krokene P, Krekling T, Lönneborg A, Solheim H. Induced responses to pathogen infection in Norway spruce phloem: changes in polyphenolic parenchyma cells, chalcone synthase transcript levels and peroxidase activity. Tree physiol. 2004;24:505-15.

61. Nagy NE, Franceschi VR, Kvaalen H, Solheim H.. Callus cultures and bark from Norway spruce clones show similar cellular features and relative resistance to fungal pathogens. Trees 2005;19(6):695-703.

62. Nebeker T and Hodges J. Host response to bark beetle and pathogen colonization. Schowalter GF (Ed). In: Beetle - pathogen interactions in conifer forests, San Diego, Academic, 1993;157-173 pp.

63. Noctor G, Arisi A-CM, Jouanin L, Kunert KJ, Rennenberg $\mathrm{H}$, Foyer $\mathrm{CH}$. Glutathione: biosynthesis, metabolism and relationship to stress tolerance explored in transformed plants. J. Exp. Bot. 1998;49:321;623-647.

64. Noctor G. Metabolic signalling in defence and stress: the central roles of soluble redox couples. Plant Cell Environ. 2006;29:409-425.

65. Noctor G, Mhamdi A, Chaouch S, Han Y, Neukermans J, Marquez-Garcia B, Queval G in Foyer CH. Glutathione in plants: an integrated overview. Plant Cell Environ. 2012;35(2):454-484.

66. Novak M, Urbanek Krajnc A, Lah L, Zupanec N, Kraševec $\mathrm{N}$, Križman M, Bohlmann J, Komel R. Low density Ceratocystis polonica inoculation of Norway spruce (Picea abies) triggers accumulation of monoterpenes with antifungal properties. Eur. J. For. Res. 2014;133:573583.

67. Novak M. Cytochromes P450 from blue-stain fungi involved in monoterpene biotransformation. Univerza v Ljubljani. Medicinska fakulteta. Doktorska disertacija 2014.

68. Paine TD, Raffa KF, Harrington TC. Interactions among Scolytid bark beetles, their associated fungi, and live host conifers. Ann. Rev. Entomol. 1997;42:179-206.

69. Percival GC. Induction of systemic acquired disease resistance in plants: Potential implications for disease management in urban forestry. J. Arboric. 2001;27(4):181-192.

70. Pont V and Pezet R. Relation between the chemical structure and the biological activity of hydroxystilbenes against Botrytis cinerea. J. Phytopathol. 2008;130(1):1-8.

71. Raffa KF, Aukema BH, Bentz BJ, Carroll AL, Hicke JA, Turner MG, Romme WH. Cross-scale drivers of natural disturbances prone to anthropogenic amplification: The dynamics of bark beetle eruptions. BioScience 2008;58:501.

72. Ralph SG, Yueh H, Friedmann M, Aeschliman D, Zeznik JA, Nelson CC, Butterfield YSN, Kirkpatrick R,
Liu J, Jones SJM et al. Conifer defence against insects: microarray gene expression profiling of Sitka spruce (Picea sitchensis) induced by mechanical wounding or feeding by spruce budworms (Choristoneura occidentalis) or white pine weevils (Pissodes strobi) reveals large-scale changes of the host transcriptome. Plant Cell. Environ. 2006;29:1545-1570.

73. Riedle-Bauer M. Role of reactive oxygen species and antioxidant enzymes in systemic virus infections of plants. J. Phytopathol. 2000;148:297-302.

74. Rodrigues, KCS, Fett-Neto AG. Oleoresin yield of Pinus elliottii in a subtropical climate: Seasonal variation and effect of auxin and salicylic acid-based stimulant paste. Ind. Crops Prod. 2009;30:316-320.

75. Rohde M, Waldmann R, Lunderstädt. Induced defence reaction in the -phloem of spruce (Picea abies) and larch (Larix decidua) after attack by Ips typographus and Ips cembrae. Forest. Ecol. Manag. 1996;86:51-59.

76. Sallé A, Monclus R, Yart A, Garcia J, Romary PLF. Fungal flora associated with Ips typographus: frequency, virulence, and ability to stimulate the host defence reaction in relation to insect population levels. Can. J. For. Res. 2005;35:365-373.

77. Schmidt A, Zeneli G, Hietala AM, Fossdal CG, Krokene P, Christiansen E, Gershenzon J. Induced chemical defenses in conifers: Biochemical and molecular approaches to studyung their function. In: Schmidt A, Zeneli G, Hietala AM, Fossdal CG, Krokene P, Christiansen, Gershenzon J,Romeo JT (Eds). Chemical ecology and phytochemistry in forest ecosystems, Vol. 39. Elsevier, Amsterdam, 2005;1-28.

78. Six DL and Wingfield MJ. The role of phytopathogenicity in bark beetle-fungus symbioses: a challenge to the classic paradigm. Ann. Rev. Entomol. 2011;56:255-72.

79. Sjostrom E. Wood chemistry, fundamentals and applications. Second Edition. Academic press, Inc., Harcourt Brace Jovanovich, Boston, London, Sydney, Tokyo, Toronto, 1993;293.

80. Smirnoff $\mathrm{N}$ and Wheeler GL. Ascorbic acid in plants: biosynthesis and function. Crit. Rev. Plant. Sci. 2000;19:267-290.

81. Smith GD, Carroll AL, Lindgren BS. Facilitation in bark beetles: endemic mountain pine beetle gets a helping hand. Agric. For. Entomol. 2011;13:37-43.

82. Šuštaršič S. Kako meriti stres pri rastlinah? Univerza v Ljubljani, Biotehniška fakulteta. Diplomski projekt 2012.

83. Tausz M, Wonisch A, Grill D, Morales D, Jiménez MS. Measuring antioxidants in tree species in the natural environment: from sampling to data evaluation. J. Exp. Bot. 2003;54(387):1505-1510.

84. Tausz M, Šircelj H, Grill D. The glutathione system as a stress marker in plant ecopysiology: is a stress-response concept valid? J. Exp. Bot. 2004;55(404):1955-1962.

85. Tegischer K, Tausz M, Wieser G, Grill D. Tree-age and needle-age dependent variations of antioxidants and photoprotective pigments in spruce needles at the alpine timberline. Tree Physiol. 2002;22:591-596.

86. Torres P, Avila JG, Romo de Vivar A, García AM, Marín JC, Aranda E, Céspedes CL. Antioxidant and insect growth 
regulatory activities of stilbenes and extracts from Yucca periculosa. Phytochemistry 2003;64:463-473.

87. Urbanek Krajnc A. Effects of endogenously increased levels of thiol compounds and salicylic acid on Zucchini yellow mosaic virus infected Styrian oil pumpkin plants. Thesis. Uni Graz. 2004.

88. Urbanek Krajnc A. A temporal analysis of antioxidative defense responses in the phloem of Picea abies after attack by Ips typographus. Tree Physiol. 2009;29:1059-1068.

89. Urbanek Krajnc A, Kristl J, Ivancic A. Application of salicylic acid induces antioxidant defense responses in the phloem of Picea abies and inhibits colonization by Ips typographus. ForEcol Manage. 2011;261:416-426.

90. Urbanek Krajnc A, Novak M, Felicijan M, Kraševec N, Lešnik $M$, Zupanec N, Komel R. Antioxidative response patterns of Norway spruce bark tolow-density Ceratocystis polonica inoculation. Trees 2014;28(4):1145-1160.

91. Veberič R. Bioactive compounds in fruit plants. el. knjiga. Ljubljana. Narodna in univerzitetna knjižnica, Biotehniška fakulteta. 2010. (URL): http://www.bf.unilj.si/agronomija/ooddelku/katedre-in-druge-org-enote/ za-sadjarstvo-vinogradnistvo-invrtnarstvo/sadjarstvo/

92. Viiri H, Annila E, Kitunen V, Niemelä P. Induced responses in stilbenes and terpenes in fertilized Norway spruce after inoculation with blue-stain fungus Ceratocystis polonica. Trees 2001;15:112-122.

93. Wallis C, Eyles A, Chorbadjian R, McSpadden Gardener B, Hansen R, Cipollini D, Herms DA, Bonello P. Systemic induction of phloem secondary metabolism and its relationship to resistance to a canker pathogen in Austrian pine. New Phytol. 2008;177:767-778.

94. Wermelinger B. Ecology and management of the spruce bark beetle Ips typographus-a review of recent research. Forest Ecol Manag. 2004; 202(1-3):67-82.

95. Whitney H. Relationships between bark beetles and symbiotic organisms. Mitton J, Sturgeon K (Eds). In: Bark beetles in north American conifers. Austin: Univ. Texas, 1982;183-211pp.

96. Witzell J, Martın JA. Phenolic metabolites in the resistance of northern forest trees to pathogens - past experiences and future prospects. Can. J. For. Res. 2008;38:27112727.

97. Woods JA, Hadfield JA, Pettit GR, Fox BW, McGown AT. The interaction with tubulin of a series of stilbenes based on combretastatin A-4. Br. J. Cancer 1995;71:705-711.

98. Xiang C, Werner BL, Christensen EM and Oliver DJ. The biological functions of glutathione revisited in arabidopsis transgenic plants with altered glutathione levels. Plant Physiol. 2001;126:564-574.

99. Zechmann B, Zellnig G, Urbanek Krajnc A and Muller M. Artificial elevation of glutathione affects symptom development in ZYMV-infected Cucurbita pepo L. plants. Arch. Virol. 2007;152:747-762.

100. Zeneli G, Krokene P, Christiansen E, Krekling T, Gershenzon J. Methyl jasmonate treatment of mature Norway spruce (Picea abies) trees increases the accumulation of terpenoid resin components and protects against infection by Ceratocystis polonica, a bark beetleassociated fungus. Tree Physiol. 2006;26:988-997.

101. Zhao FJ, Tausz M, De Kok LJ. Role of sulfur for plant production in agricultural and natural ecosystems. In: Hell R, Dahl C, Knaff D, Leustek T (Eds). Advances in photosynthesis and respiration. Springer, Dordrecht 2008;417-435.

\section{Antioksidativni obrambni odziv lubja navadne smreke ob napadu podlubnikov in z njimi povezanimi glivami modrivkami}

\section{IZVLEČEK}

Čeprav so podlubniki in z njimi povezane glive sestavni del gozdnih ekosistemov, sta osmerozobi smrekov lubadar (Ips typographus Linnaeus) in z njim povezana patogena gliva modrivka [Ceratocystis polonica (SiEm.) C. Moreau], ena najbolj uničujočih škodljivcev navadne smreke [Picea abies (L.) H. KARsTEN]. Lubadarji navadno naseljujejo oslabela in podrta drevesa, v specifičnih pogojih pa lahko napadejo tudi vitalna. S poškodbami floema in kambija ter motnjo transpiracijskega toka v ksilemu, drevesu povzročijo številne fiziološke motnje. Iglavci imajo široko paleto obrambnih mehanizmov, ki temeljijo na anatomiji lubja in fiziološkem stanju drevesa. Njihova osnovna funkcija je zaščita hranilno in energetsko bogatega floemskega tkiva, meristematske aktivnosti vaskularnega kambija in transpiracijskega toka v sekundarnem ksilemu debla. Glavno področje obrambnih mehanizmov je namreč sekundarni floem, ki predstavlja fizično in kemično zaščito lubja pred škodljivci, saj vsebuje polifenolne parenhimatske celice, sklerenhim, kristale kalcijevega oksalata in shizogene smolne kanale. Obrambni sistem lubja iglavcev zajema tri vrste obrambnih strategij - konstitutivno in inducirano obrambo ter sistemsko pridobljeno odpornost. Konstitutivna in inducirana obramba zavirata kolonizacijo podlubnikov, rast gliv in zapirata ranitvena mesta. Med uspešnim napadom pa je za drevo ključnega pomena še vzpostavitev sistemsko pridobljene odpornosti (SAR). Le ta se postopoma širi po rastlini ter izzove sistemske spremembe v metabolizmu drevesa, ki se ohranjajo skozi daljše časovno obdobje. Med številnimi obrambnimi odzivi, povezanimi $\mathrm{z}$ aktivacijo SAR, sta pomembni sinteza antioksidantov in aktivacija antioksidativnih encimov, ki varujejo rastlino pred reaktivnimi kisikovimi spojinami (ROS). Prispevek zajema pregled dosedanjega znanja o strategijah antioksidativnega odziva lubja smreke pri napadu smrekovega lubadarja (Ips typographus) in z njim povezane patogene glive modrivke (Ceratocystis polonica). 